\title{
Short Report: Flash Flooding in East Azerbaijan Province, Iran: A Field Report
}

\author{
Javad Babaie ${ }^{1^{*}}$ (D), Mohsen Noori ${ }^{2}$, Moslem Sarani ${ }^{3}$, Fatemeh Sadeghi ${ }^{4}$
}

1. Health Services Management Research Center, School of Management and Medical Informatics, Tabriz University of Medical Sciences, Tabriz, Iran. 2. Department of Health in Disasters and Emergencies, School of Public Health, Tehran University of Medical Sciences, Tehran, Iran. 3. Department of Diseases Control and Prevention, Vice Chancellor for Health, Golestan University of Medical Sciences, Gorgan, Iran. 4. Department of Preventive Maintenance, East Azerbaijan's Water and Waste Water Company, Tabriz, Iran.

\begin{tabular}{|l|l|}
$\begin{array}{c}\text { Use your device to scan } \\
\text { and read the article online }\end{array}$ & $\begin{array}{l}\text { Ettation Babaie J, Noori M, Sarani M, Sadeghi F. Flash Flooding in East Azerbaijan Province, Iran: A Field Report. Health in } \\
\text { Emergencies and Disasters Quarterly. 2019; 4(2):109-111. http://dx.doi.org/10.32598/hdq.4.2.109 }\end{array}$ \\
doi: $:$ http://dx.doi.org/10.32598/hdq.4.2.109
\end{tabular}

\section{(c) (i) \$}

Article info:

Received: 28 Jul 2018

Accepted: 10 Nov 2018

Available Online: 01 Jan 2019

\section{Keywords:}

Flash flood, Flood, Natural hazards, Iran

\begin{abstract}
On Friday, 14 April 2017, a heavy flash flood occurred in North-West of Iran that affected 12 cities; the most severely affected and damaged ones were Ajabshir and Azarshahr in East Azerbaijan Province. These Flash floods claimed the lives of 42 people. Major casualties occurred when the victims were trapped inside their cars. According to preliminary analyses, flood damages in East Azerbaijan Province are estimated to be around three trillion Rials. Following the Flash floods, disaster relief organizations were activated. Iranian President, Minister of Energy, and the provincial authorities rushed to visit flood-stricken areas and oversee the rescue and relief operations.
\end{abstract}

\section{Introduction}

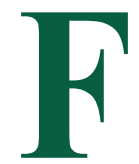

lood refers to circumstances in which streams, rivers, or other collections of water, natural or synthetic, overflow. Floods are caused by rain, melting snow, or failure in structures holding water $[1,2]$. Floods are the most common natural disasters in the world [3] and are blamed for 40-50\%of all disasters and their deaths [1]. According to EmDAT database, excluding tsunamis [4], 38.7\% of all disasters are due to the floods, and the cause of $43 \%$ of the population is affected by the disasters that occurred from 2000-2009 [1].

An alarming point about the floods is the scale/magnitude of their incurred losses and damage in the world in recent decades. Iran is a flood and Flash flood prone country. In Iran, a flood occurs every nine days. Seventeen cities are highly vulnerable to floods. One and two villages are, on average, affected by floods every three days and every 20 days, respectively [5]. The figures on floods in Iran also reflect the increasing occurrence of this phenomenon in recent decades [3] and consequently a rise in its life and property losses $[6,7]$.

\section{Flash Flood Impact}

In East Azerbaijan Province in Iran, following a heavy rainfall on Friday, 14 April 2017 in some Southern districts of the province, Flash floods took place leading to landslides in some areas. The worst Flash floods oc-

\section{* Corresponding Author:}

Javad Babaie, PhD.

Address: Health Services Management Research Center, School of Management and Medical Informatics, Tabriz University of Medical Sciences, Tabriz, Iran E-mail:javad1403@gmail.com 
curred in the cities of Azarshahr and Ajabshir. Heavy rain and the probability of Flash flood occurrence were anticipated, and necessary warnings were issued too.

In Ajabshir, heavy rain, accompanied by hail, began and lasted 10 minutes, and led to a huge and sudden Flash flood in the villages of Chinar, Dizaji, and Khanian. Although most casualties occurred in the village of Chinar, flooding was so severe that trees and multiton rocks were also washed away. The Flash floods affected 2984 people, injured eight, killed 20, and completely demolished 15 houses. Drinking water distribution pipes were broken and drinking water sources were contaminated. During the 12-day search and rescue operations, 19 lost bodies were found and identified. However, the body of an infant, presumably buried under mud, is not yet spotted. The start of the flood was very sudden and surprising for many, despite previous warnings. Sudden onset of the Flash floods denied any effective response opportunities, and victims were just watching flooding.

In Azarshahr, while people were having fun or picnicking in grain farms, the Flash flood flowed in the river locally referred to as 'Dry River', since it is most often dry, and the ones settled in the vicinity of the river banks or passing by lost their lives. The floods resulted in 22 human losses. The bodies of the lost people were found in the mud after four days. In Azarshahr, 3500 people in five villages were affected. Most of the victims in Azarshahr lost their lives while driving, moving, or trying to save their cars from the Flash floods.

Local officials and people did not believe that this river named SelChayi literally "Flood River" (In English) could overflow and outburst. Therefore, in order to facilitate transportation of vehicles and traffic into the main road, an underpass was set up under the main bridge over this river. Several passing cars on the track were caught in flood, while crossing through the underpass (seven vehicles with 22 passengers). There are some allegations and video footage indicating that a few even got trapped and drowned in the flood as they came nearby to watch the ongoing flood.

\section{Lessons Learned from This Flood Disaster}

Iran has more than 3500 rivers of varying sizes. Many towns and villages in Iran are built in flood run-out areas or at the mouth of the valleys. These towns and villages repeatedly experienced floods in the course of history. Nonetheless, over the past years, due to a long period of drought or low rate of precipitation, people have gradual- ly come under the impression and assumption that there will no longer be a flood. Hence, they have embarked upon making constructions in this direction and have consequently blocked or narrowed waterways. Moreover, loss of vegetation and construction of residential and non-residential structures along with asphalted areas have compounded the situation, leading to a reduction in rain water absorption and acceleration of water flowing in this region. At a macro-level, climatic and precipitation changes could also contribute to the occurrence of these Flash floods.

Iran Meteorological Organization can forecast floods and other meteorological hazards. These forecasts and warnings are regularly released to inform the public through mass media. Unfortunately, such warnings and alerts are not taken seriously by many people. In general, it can be concluded that risk perception is low, and rarely do precautionary warnings effectively. Such alerts and notifications lose their significance especially at times when people are together. Failing to note the issued warning, some get caught in floods. For example, it is evident that a good number of the killed were in their cars as the flood caught them. Though with a very heavy human and material prices, the lessons learned out of this tragedy are that the general public in Iran should take risk warnings very seriously, and systematic measures should be taken to raise risk awareness and perception nationwide on the part of the government and other responsible bodies.

\section{Ethical Considerations}

\section{Compliance with ethical guidelines}

There is no ethical principle to be considered doing this research.

\section{Funding}

This research did not receive any specific grant from funding agencies in the public, commercial, or not-forprofit sectors.

\section{Authors contributions}

All authors contributed in preparing this article.

\section{Conflict of interest}

The authors declare no conflict of interest. 


\section{References}

[1] Weiwei Du, Gerard JFG, Clark M, Hou XY. Health impacts of floods. Prehospital and Disaster Medicine. 2010; 25(3):26572. [DOI:10.1017/S1049023X00008141]

[2] Ciottone G, Anderson PH, Der Heide EA, Darling R, Jacoby I, Noji N, et al. Disaster Medicine. Amsterdam: Mosby Elsevier; 2006.

[3] Ardalan A, Holakouei Naeini K, Honarvar Mohammad R, Kabir MJ, Zanganeh AM, Keshtkar Abas A, et al. [The early warning system for flash floods in Golestan Province: The model of village disaster taskforce (Persian)]. Payesh. 2009; 2(8):147-54.

[4] Center for Research on Epidemiology of Disasters (CRED). Disasters profiles. [Cited 20 October 2012]. Available from: https:/ / www.emdat.be/index.php?disgroup=natural\&peri od $=1900 \% 242013 \&$ dis_ty

[5] Heidari A, Emami K, Bekhordar M. Early flood warning systems. Tehran: Iranian National Committee on Irrigation and Drainage; 2006.

[6] Velayati S, Jahani M, Ramesh A. [Importance of flood risk management in rural planning: Case study Kardeh Basin (Persian)]. Geographia \& Development. 2006; 4(4):69-87.

[7] Rahmati O, Pourghasemi HR, Zeinivand H. [Flood susceptibility mapping using frequency ratio and weight-of-evidence model in the Golestan Province, Iran (Persian)]. Journal of Geocrato International. 2016; 31(1):1-29. 